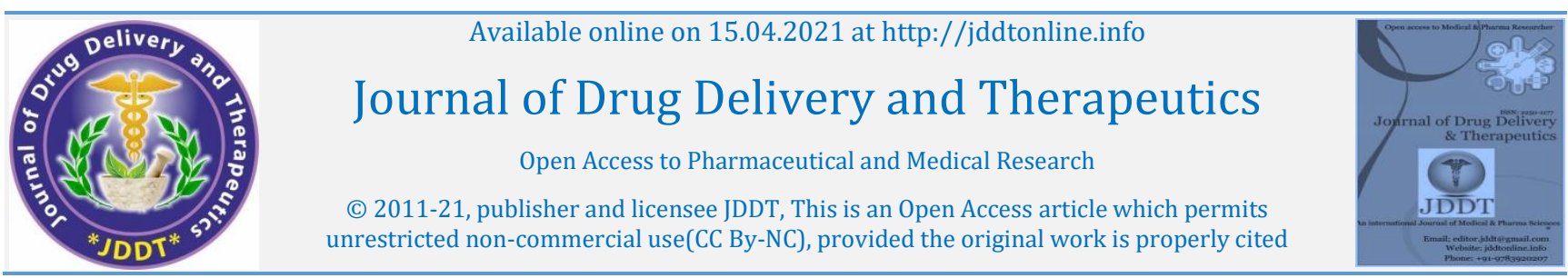

(C) 2011-21, publisher and licensee JDDT, This is an Open Access article which permits
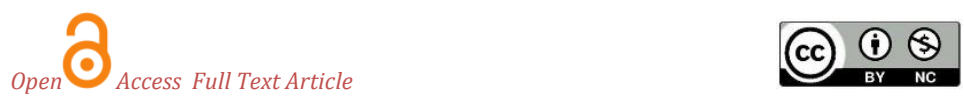

Research Paper

\title{
Evaluation of Analgesic Effect of Unani Pharmacopoeial Formulation Habb-E-Suranjan and Raughan-E-Suranjan in Wajaul Mafasil (Joints Pain) Patients: An Open Prospective Clinical Trial
}

\author{
Kabiruddin Ahmad', N Zaheer Ahmed *1, R Ezhil ${ }^{1}$, Nighat Anjum², Asim Ali Khan ${ }^{2}$ \\ ${ }^{1}$ Regional Research Institute of Unani Medicine, Chennai, India \\ ${ }^{2}$ Central Council for Research in Unani Medicine, New Delhi, M/o AYUSH, Govt of India
}

\begin{abstract}
Article Info:

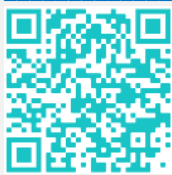

Article History:

Received 17 Feb 2021

Review Completed 24 March 202

Accepted 29 March 2021

Available online 15 April 2021

Cite this article as:

Ahmad K, Ahmed NZ, Ezhil R, Anjum N, Khan AA,

Evaluation of Analgesic Effect of Unani Pharmacopoeial

Formulation Habb-E-Suranjan and Raughan-E-Suranjan in Wajaul Mafasil (Joints Pain) Patients: An Open

Prospective Clinical Trial, Journal of Drug Delivery and

Therapeutics. 2021; 11(2-s):44-49

DOI: http://dx.doi.org/10.22270/jddt.v11i2-s.4806

*Address for Correspondence:

N Zaheer Ahmed, Regional Research Institute of Unani Medicine, Chennai, India

Abstract

Wajaul Mafasil (joint pain) is the most prevalent and common cause of morbidity and disability not only in India but also throughout the world. In spite of various scientific developments in conventional medicine, there is no specific therapy or cure available for joints pain particularly when the disease has progressed to chronic stage. Therefore, it is the need of the hour to explore new formulations from herbal sources which are safe and effective. The present trial was undertaken to scientifically validate the Unani pharmacopoeial compound formulations of Habb-e-Suranjan and Raughan-e-Suranjan for its safety and efficacy in patients with joints pain.

Patients with joint pain, who gave written informed consent, were recruited in the study from general OPD of RRIUM, Chennai with the prior approval of the Institutional Ethics Committee. 97 patients completed the study treatment. The treatment protocol was followed for 14 days and the clinical evaluation was done on seventh and fourteenth day of the treatment. At the end of fourteenth day intensity of individual parameters like joints pain, swelling, tenderness and restriction of movement showed statistically significant improvement $(\mathrm{p}<0.05)$. Overall therapeutic response of the treatment observed in this study was $100 \%$. It was observed that $47.4 \%$ cases were completely relieved; $51.4 \%$ cases were relieved while $1.2 \%$ cases showed partial relief after the treatment. The laboratory investigations showed that the drugs used in the study were safe as evident by its maintenance. It may be concluded that Habb-e-Suranjan in combination with Raughan-e-Suranjan possesses significant analgesic property and may be a better option for the patients of joint pain.
\end{abstract}

Keywords: Arthritis, Joints pain, Wajaul Mafasil, Habb-e-Suranjan, Raughan-e-Suranjan

\section{INTRODUCTION}

The history of Wajaul Mafasil (joints Pain) is as old as the history of human being. Hippocrates presented the first compendium on the disease known as Kitab-ul-Mafasil which deals with joint diseases (Mohammad et al., 2014) ${ }^{1}$. Wajaul Mafasil is an Arabic word which literally means pain of the joints. Joint pain is the most prevalent symptoms in medical practice and one among the leading causes of disability worldwide (Neogi, 2016; Finney et al., 2017)2. Arthritis is one of the commonest joint disorder affecting millions of people worldwide with an estimated 15\% (40 million) of Americans had some form of arthritis in 1995 and in India it affects 15\% (180 million) people (Ashraf \&Mohiud-din, 2018) ${ }^{3}$. The causes of joints pain include trauma, inflammation, infection, degeneration and metabolic disorders. Degenerative arthritis is much more common in old age but other types of arthritis such as rheumatoid arthritis, septic arthritis, rheumatic arthritis, gonococcal arthritis and gouty arthritis may affect to all age groups of people. The common symptoms of arthritis are pain, stiffness and swelling, but the presentation of symptoms is different according to the types of arthritis. In osteoarthritis, large joints are commonly affected and distribution of pain is usually asymmetrical in manner, while in rheumatoid arthritis, usually small joints are affected in symmetrical fashion. In acute gouty arthritis, very severe pain in first metatarso-phalangeal joint is occurred particularly at night (Munjal YP, 2012) ${ }^{4}$.

The aetiology, pathology and principle of treatment of Wajaul Mafasil has been discussed in detail in Unani System of medicine (Faris, A.A. 2010)5 (Masuya, Y.B. 1994) ${ }^{6}$ (Majusi, A.A.1889) ${ }^{7}$ (Qarah, S.B. 1928) ${ }^{8}$ (Razi, Z. 2004) ${ }^{9}$ (Rushd, I. 1987) ${ }^{10}$ (Siddiqui, M.K.2009) ${ }^{11}$ (Tabri,A.R. 1417) ${ }^{12}$ (Jurjani A.H 2010) ${ }^{13}$ (Sina I 2004) ${ }^{14}$. Unani scholars have defined Wajaul Mafasil as the pain and inflammation which develops in the organs and surrounding structures of joints, such as synovial membrane, cartilage, ligaments, tendons and muscles. According to Razi, Wajaul Mafasil is one of those disorders which occur in the form of recurrent or 
paroxysmal attacks and caused by accumulation of excessive Ratubat (fluid). Razi also quoted that Wajaul Mafasil is a wide term that encompasses pain of joints, Niqras(gout) and Irq-un-Nisa(sciatica) (Mohammad et al 2014)1'. Ismail Jurjani has stated that the accumulation of mawaade fuzooni (morbid matters) in the structures of joint results in inflammation and pain in joint (Antaki, 1282) ${ }^{15}$. Pain occurs in joints where there is a decrease in Hararat-e-Ghariziya which causes slow absorption of the morbid humors leading to accumulation of waste matter in the joints. It is a very common problem of old age but may start at earlier stage of life specially when there is predominance of Balgham along with obesity, indigestion, prolonged breast-feeding, poverty, damp, exposure to cold and humid climates (Kabeeruddin, 2007) ${ }^{16}$.

Based on the dominant morbid matters affecting the joints, it is stated that the Balgham (phlegm) predominates over Dam (Blood) followed by Safra (bile) and Sawda (black bile) is rarely involved. In some cases, more than one khilt (Humours) are involved (Kabeeruddin, 2003)17. Wajaul Mafasil Balghami (Phlegmatic) is the Commonest form of Wajaul Mafasil where the onset of symptoms and sign are gradual, area of affected joint is swollen, soft, whitish and cold on touch, pain and throbbing is nominal, swelling is soft and cold with deep pain and tenderness marked, pain aggravates by exposure of cold and relieves by exposure of heat over affected part, generalized and localized symptoms of dominance of phlegm (Ghalbae Balgham) will be present (Baig MG,2014)18.Unani system of medicine is replete with many treatment regimens for joints pain. A number of single and compound drugs are in vogue since ages for joint pain and other musculoskeletal disorders. Habb-e-Suranjan and Raughan-e-Suranjan are two important and commonly prescribed formulations for the treatment of joint pain.

\section{Study rationale}

Joint pain is the most prevalent and common cause of morbidity and disability worldwide. In Unani System of Medicine, arthritis is described under a broad term Wajaul Mafasil, which encompasses entire joint disorders like inflammatory, non-inflammatory, infectious, metabolic and other musculoskeletal disorders. The main aim of treatment of Wajaul Mafasil (joint pain) is to reduce morbidity and disability. In spite of various scientific developments in conventional medicine, there is no specific therapy or cure available for joints pain particularly when the disease has progressed to chronic stage. Therefore, it is the need of the hour to explore new formulations from herbal sources which are safe and effective. Classical literature reveals that these two pharmacopoeial preparations i.e., 'Habb-e-Suranjan' and 'Raughan-e-Suranjan' are not only effective in treatment of joints pain, they are also safe and devoid of adverse effect. Though the drug has been in use since centuries, no clinical data is available as to its safety and efficacy. Hence, an open prospective clinical study was conducted at RRIUM, Chennai to assess the analgesic activity of the above two formulations in the relief of joints pain in patients with Wajaul Mafasil. This study may also be useful in commercialization of these two pharmacopoeial preparations in future.

\section{MATERIAL AND METHODS}

An open prospective clinical trial was carried out on total number of 106 patients of Wajaul Mafasil (Joint Pain) of which 9 participants was lost to follow-up due to varied reasons and 97 patients completed the trial. The study was approved by the Institutional Ethics Committee (IEC), RRIUM, Chennai. The study was conducted at Regional Research Institute of Unani Medicine, Chennai, during the period of May 2013 to May 2014. Patients were registered after getting voluntary informed consent to participate in the study. Patients of Wajaul Mafasil (Joint pain) in the age group 18 - 65 years of either gender presenting with or without any of the symptoms/ signs such as Pain, Tenderness, Swelling and Restriction of movement involving Single / multiple joints were included in the study. The patients who fulfil the inclusion criteria were explained regarding the dosage, duration and purpose of the study. Patients having disorders requiring long term treatment like Diabetes Mellitus, Hypertension, known cases of hepatic, renal or cardiac ailments, pregnant and lactating women and patients with history of alcohol or drug abuse were excluded from the study.

\section{Details of Intervention}

The test formulation, Habb-e-Suranjan containing powder of three herbs Elwa/Sibr (Aloe barbadensis), Halela (Terminalia chebula), Suranjan (Colchicum luteum) in equal proportion (Kabeeruddin, 2005) ${ }^{19}$ and Raughan-e-Suranjan (Colchicum luteum oil) (Anonymous, 196720, Anonymous, 2006) ${ }^{21}$ were prepared as per standard procedure under the supervision of chief pharmacist at GMP certified pharmacy, of CRIUM, Hyderabad and supplied to the study site. Two tablets of Habb-e-Suranjan (500mg each) were given thrice a day after meals with water or milk for two weeks along with Raughan$e$-Suranjan for which patients were advised to apply $5 \mathrm{ml}$ lukewarm oil locally on affected joints in the morning and evening twice daily for two weeks.

Clinical parameters were assessed at base line, seventh day and fourteenth day of the treatment period. The temperament of the patients was recorded at base line and on completion of the treatment. The subjective and objective clinical observations were recorded in the CRF. For assessment of the efficacy of drugs; joints pain, tenderness, joints swelling and restriction of movement were scored on the grading basis from 1-4 at baseline and each follow ups. Percentage efficacy was calculated from reduction of scores.

The safety parameters were assessed by recording of adverse events and carrying out laboratory investigations. Laboratory investigations were carried out at baseline and on the last follow-up date.

\section{Criteria for assessment of result:}

The criteria for assessment of result of the study was based on the following:

(a) 90-100\% improvement in clinical symptoms \& signs = completely relief.

(b) 60-89\% improvement in clinical symptoms \& signs = Relief.

(c) $30-59 \%$ improvement in clinical symptoms \& signs = Partial relief.

(d) $<30 \%$ improvement in clinical symptoms \& signs $=$ Not relieved.

\section{Statistical analysis}

The discrete variable was expressed as percentage and continuous variables were expressed as mean with standard deviation. To assess the mean score changes of sign and symptoms between the baseline and after the treatment non parametric test was applied. Paired t-test was used to test the significance. All tests were two tailed and P-value $<0.05$ was considered as significant. 


\section{RESULTS}

Table 1: Demographic profile of Wajaul Mafasil (Joint Pain) patients $(n=97)$,

\begin{tabular}{|l|l|}
\hline Characteristics & No. (\%) \\
\hline Age (Year) & $28(28.9)$ \\
$41-50$ & $44(45.4)$ \\
$51-65$ & $25(25.8)$ \\
Mean age \pm Sd & $45.4 \pm 10.43$ \\
\hline Gender & \\
Male & $33(34.0)$ \\
Female & $64(66.0)$ \\
\hline Duration of disease (Month) & $91(93.8)$ \\
$<=12$ & $6(6.2)$ \\
$>12$ & $7(7.2)$ \\
\hline Mizaj & $25(25.8)$ \\
Damavi (Sanguine) & $65(67.0)$ \\
\hline Balghami(Phlegmatic) & \\
Safravi(Choleric) & \\
\hline
\end{tabular}

The age distribution shows that $28.9 \%$ of the study subjects were less than 40 years and in the other two age groups the percentage was $45.4 \%$ and $25.8 \%$. The mean age of the study subjects was $45.4 \pm 10.42$ years. The proportion of male and female in the study was recorded to be $34 \%$ and $66 \%$ respectively. About $94 \%$ percent of study subjects had joint pain for a duration of less than or equal to 12 months. The percentage of patients observed in Damavi (Sanguine), Balghami (Phlegmatic), and Safravi (Choleric) were 7.2\%, $25.8 \%$ and $67 \%$ respectively. (Table 1 ).
Table 2: Response of treatment based on reduction score percentage in patients of Wajaul Mafasil (Joint pain) treated with Habb-e-Suranjan and Raughan-eSuranjan

\begin{tabular}{|l|l|l|}
\hline Response & No. & \% \\
\hline Complete relief & 46 & 47.4 \\
\hline Relief & 50 & 51.4 \\
\hline Partial relief & 1 & 1.2 \\
\hline Total & 97 & 100.0 \\
\hline
\end{tabular}

With the active intervention of Unani Pharmacopoeial formulation Habb-e-Suranjan and Raughan-e-Suranjan, the analysis was done on 97 cases and found the overall therapeutic response to be $100 \%$

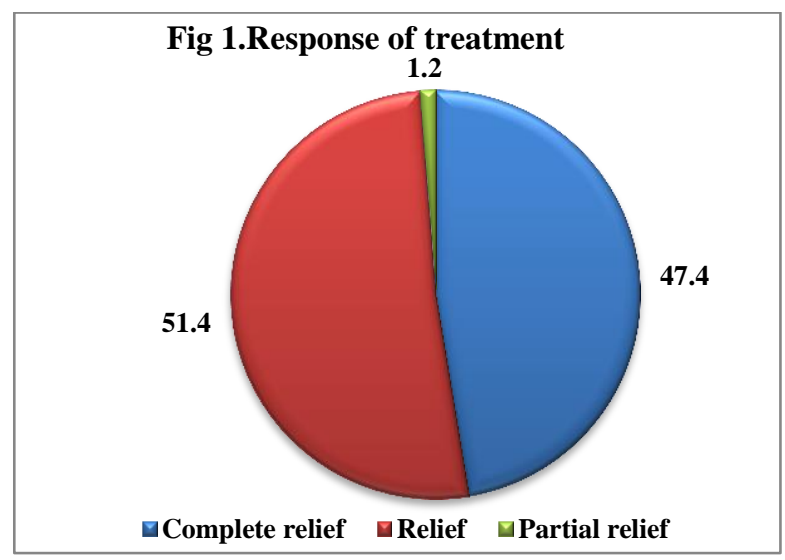

Figure 1: Response of treatment

The treatment response of complete relief, relief and partial relief were $47.4 \%, 51.4 \%$ and $1.2 \%$ respectively as depicted in Table 2 \& Figure 1

Table 3: Reduction in mean score of sign and symptoms during the follow up period in patients of Wajaul Mafasil (Joint pain) treated with Habb-e-Suranjan and Raughan-e-Suranjan

\begin{tabular}{|l|l|l|l|l|}
\hline Sign \& symptoms & $\begin{array}{l}\text { Base line } \\
\text { Mean } \pm \text { Sd }\end{array}$ & $\begin{array}{l}\text { 1stFollow-up } \\
\text { Mean } \pm \text { Sd }\end{array}$ & $\begin{array}{l}\text { 2ndFollow-upMean } \\
\mathbf{\mathbf { S d }}\end{array}$ & P-value \\
\hline Joint Pain & $3.00 \pm 0.0$ & $1.7 \pm 0.64$ & $0.72 \pm 0.61$ & $<0.05$ \\
\hline Tenderness & $3.00 \pm 0.0$ & $1.5 \pm 0.66$ & $0.49 \pm 0.60$ & $<0.05$ \\
\hline Joint Swelling & $2.68 \pm 0.49$ & $0.64 \pm 0.86$ & $0.09 \pm 0.36$ & $<0.05$ \\
\hline Restriction of Movements & $3.00 \pm 0.0$ & $1.6 \pm 0.63$ & $0.58 \pm 0.57$ & $<0.05$ \\
\hline
\end{tabular}

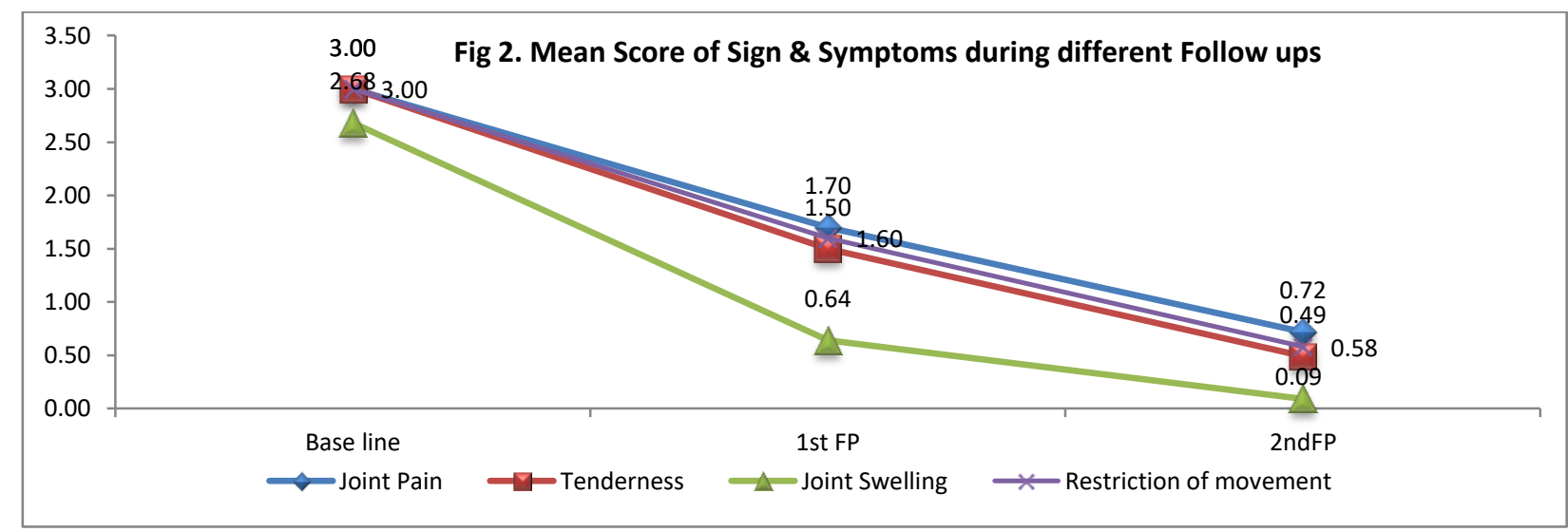

Figure 2: Mean Score of Sign \& Symptoms during different Follow ups 
The mean score of all the four sign and symptoms of the Waja'al-Mafāșil patients were significantly $(\mathrm{P}<0.05)$ reduced at the last follow up. (Table 3; Fig 2)

Table 4: Subsidence of sign and symptoms of Wajaul Mafasil (Joint pain) patients treated with Habb-e-Suranjan and Raughan-e-Suranjan at baseline and after trial.

\begin{tabular}{|l|l|l|l|l|}
\hline \multirow{2}{*}{ Sign \& symptoms } & \multicolumn{2}{|l|}{ Base line } & \multicolumn{2}{l|}{ After treatment } \\
\cline { 2 - 5 } & $\begin{array}{l}\text { Present } \\
\text { No. (\%) }\end{array}$ & $\begin{array}{l}\text { Absent } \\
\text { No. (\%) }\end{array}$ & $\begin{array}{l}\text { Present } \\
\text { No. (\%) }\end{array}$ & $\begin{array}{l}\text { Absent } \\
\text { No. (\%) }\end{array}$ \\
\hline Joint Pain & $97(100.0)$ & 0 & $62(63.9)$ & $35(36.1)$ \\
\hline Tenderness & $97(100.0)$ & 0 & $43(44.3)$ & $54(55.7)$ \\
\hline Joint Swelling & $97(100.0)$ & 0 & $7(7.2)$ & $90(92.8)$ \\
\hline Restriction of movement & $97(100.0)$ & 0 & $52(53.6)$ & $45(46.4)$ \\
\hline
\end{tabular}

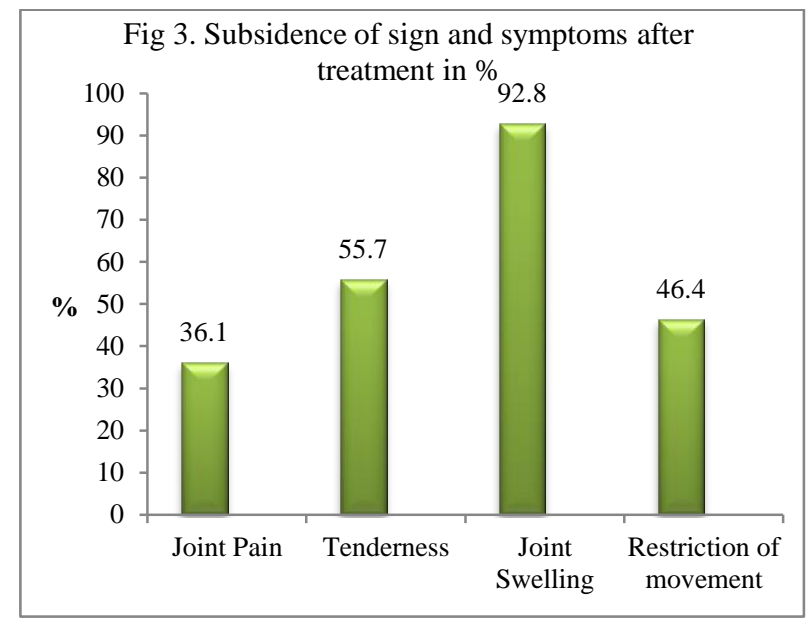

Figure 3: Subsidence of sign and symptoms after treatment in \%

On observation, the joint pain completely disappeared in $36.1 \%$ cases; tenderness in $55.7 \%$ cases, joint swelling in $92.8 \%$ cases while restriction of movement was completely disappeared in $46.4 \%$ cases. This indicates that the joint swelling has reduced to a greater extent and about half of the patients were free from tenderness and restriction of movements. (Table 4, Fig 3)

Table 5: Pathological and biochemical Parameters in Wajaul Mafasil (Joint pain) patients treated with Habb-e-Suranjan and Raughan-e-Suranjan

\begin{tabular}{|l|l|l|l|}
\hline Parameter & $\begin{array}{l}\text { Base line } \\
\text { Mean } \pm \text { S.D }\end{array}$ & $\begin{array}{l}\text { After Treatment } \\
\text { Mean } \pm \text { S.D }\end{array}$ & P-value \\
\hline Hb (Grams \%) & $13.4 \pm 1.74$ & $13.4 \pm 1.74$ & $>0.05$ \\
\hline W.B.C(Cells/Cu.mm) & $9229 \pm 2354.9$ & $9446 \pm 24770.02$ & $>0.05$ \\
\hline Neutrophils (\%) & $59 \pm 9.15$ & $57.6 \pm 9.07$ & $>0.05$ \\
\hline Lymphocytes (\%) & $34.9 \pm 8.05$ & $35.6 \pm 7.8$ & $>0.05$ \\
\hline Eosinophil (\%) & $5.5 \pm 5.06$ & $6.1 \pm 4.98$ & $>0.05$ \\
\hline Monocytes (\%) & $0.5 \pm 0.97$ & $0.71 \pm 1.14$ & $>0.05$ \\
\hline Basophils (\%) & $0.02 \pm 0.20$ & $0.0 \pm 0.0$ & $>0.05$ \\
\hline E.S.R 1sthour(\%) & $30.9 \pm 25.40$ & $30.9 \pm 27.83$ & $>0.05$ \\
\hline Blood Sugar(mg \%) & $95.8 \pm 17.86$ & - & - \\
\hline Blood Urea(mg \%) & $21.3 \pm 4.91$ & $21.8 \pm 4.20$ & $>0.05$ \\
\hline Sr.creatinine(mg \%) & $0.8 \pm 0.11$ & $0.7 \pm 0.10$ & $>0.05$ \\
\hline Sr. Bilirubin & $0.7 \pm 0.19$ & $0.6 \pm 0.10$ & $>0.05$ \\
\hline SGOT Units/L & $22.8 \pm 8.31$ & $22.9 \pm 9.40$ & $>0.05$ \\
\hline SGPT Units/L & $24.8 \pm 6.54$ & $24.5 \pm 7.21$ & $>0.05$ \\
\hline Alkaline Phosphatase KA U & $8.4 \pm 2.95$ & $8.3 \pm 2.25$ & $>0.05$ \\
\hline
\end{tabular}

The study findings revealed that all pathological and biochemical parameters were within normal range and no significant $(\mathrm{P}>0.05)$ difference in the mean value between the baseline and after the treatment was observed. 


\section{DISCUSSION:}

Wajaul Mafasilis one of the leading problems nowadays which causes physical impairment and disability in the community affecting millions of people throughout the world. Although Western medicine offers many antiinflammatory and anti-arthritic drugs but they are neither optimally effective nor safe. So, Traditional Medicines, including Tibb-e-Unani are being explored for effective and safe anti-arthritic drugs.

This clinical study was conducted on 97 patients to evaluate the efficacy of Unani Pharmacopoeial formulation Habb-eSuranjan for oral administration and Raughan-e-Suranjan for local application in the management of Waja'al-Mafāșil. The treatment response of complete relief, relief and partial relief were $47.4 \%, 51.4 \%$ and $1.2 \%$ respectively. This study revealed no adverse effects during the period of trial. A similar study carried out in Regional Research Institute of Unani Medicine, Patna, Bihar during the period of February 2013 to march 2014 with the same formulation (Mohammad IA 2018) ${ }^{22}$ revealed comparable findings which corroborates with the present study. Pain increases with age which is similar to the findings observed in a study report of national health survey (Anonymous, 2008) ${ }^{23}$. The study findings show that Joints Pain is comparably higher among females than in males which is similar to the study 'A meta-analysis of sex differences prevalence, incidence and severity of osteoarthritis' (V K Srikanth. et.al, 2005) ${ }^{24}$.

The safety and efficacy of Habb-e-Suranjan may also be comparable with other clinical studies. A clinical trial conducted at Ajmal Khan Tibbiya College and Hospital involving the patients of primary gout found that not only was Habb-e-Suranjan was clinically effective as the allopurinol but was also safe for usage (Hilal Akhtar et.al. 2019) 25 .

The findings of the study showed beneficial effects of tested formulations revealed by the improvement of clinical symptoms. The clinical improvements are mainly because of composition of the drug. The analgesic activities of Aloe, Colchicum, and sedative (Musakkin) activity of T. chebula, are responsible for relief in pain. The anti-inflammatory action of Colchicum also play a crucial role on joint pain and painful joints movement along with reduction in swelling and tenderness and may also be responsible for the favourable response in patients. The resolving and analgesic action of Colchicum is enough to explain the mechanism through which the gradual improvements happened (Hilal Akhtar et.al. 2019) ${ }^{25}$.

Both the formulations contain Suranjan as its main ingredient. Colchicine is the main alkaloid of Suranjan. Colchicine is not unfamiliar to the medical world, as it has been utilized in the treatment of gout and has been investigated in many other conditions, including familial Mediterranean fever (Shahid Suhail et.al. 2017) ${ }^{26}$.

In a review study, different Nuskhajaat (formulations) of Habb-e-Suranjaan were mentioned with their different ingredients, doses and therapeutic uses which highlighted its use and effectiveness for Waja'-al Mafasil (Arthralgia) and 'Irq al-Nasa (Sciatica) (Shahid Suhail et.al. 2017) ${ }^{27}$.

An experimental study to evaluate Sub chronic oral toxicity study of Habb-e-Suranjan in albino Wistar rats has revealed that the formulation is safe and did not induce any adverse effect in rats. (Khalid Ghazanfar et. al. 2017)28. A disease review study on Waja-ul- Mafasil has also emphasised the utility of both the formulations administered in this study (Khan AA et. Al. 2019). ${ }^{29}$

\section{CONCLUSION:}

Clinical improvement was observed in clinical sign and symptoms of Wajaul Mafasil after fourteen days of treatment with Habb-e-Suranjan and Raughan-e-Suranjan. Non-toxic nature of the drug is evident from the maintenance of laboratory parameters suggests that the drug Habb-eSuranjan and Raughan-e-Suranjan does not have hepatic or renal toxicity. Hence it may be concluded that the studied drugs are safe and effective in the treatment of Wajaul Mafasil(Joint pain). Further controlled studies with large sample size with increased dosage of the drug may throw more information on the outcome of the drug in the treatment of Wajaul Mafasil(Joint pain).

Acknowledgements: The authors are grateful to the M/o AYUSH, Govt of India for sponsoring and allotting the study to R.R.I.U.M, Chennai. The authors also duly acknowledge the contribution of a team of C.C.R.U.M Officers for their role in study protocol preparation.

Research funding: The study has been entirely funded by Central Council for Research in Unani Medicine (CCRUM), New Delhi, Ministry of AYUSH, and Government of India.

Author contributions: All the authors have accepted the responsibility for the entire content of the submitted manuscript and approved submission.

\section{Conflict of interest: None declared}

\section{REFERENCES:}

1. Mohammad SH, Faseehuzzaman, Jabeen A, Siddiqui MA Management of Waja-ul-Mafasil (Arthritis) in Unani system of Medicine- A Review. Int. J. Res. Ayurveda Pharm, 2014; 5 (1):60 -64 .

2. Finney A, Dziedzic KS, Lewis $M$ and Healey E. Multisite peripheral joint pain: a cross-sectional study of prevalence and impact on general health, quality of life, pain intensity and consultation behavior. BMC Musculoskeletal Disorders, 2017; 18:535

3. Rahila Ashraf, Roohi Mohi-ud-din. Unani aspect of arthritis (Waja-ul-Mafasil) \& its management: A review, International Journal of Herbal Medicine, 2018; 6(3).

4. Munjal YP. API Textbook of Medicine. $9^{\text {th }}$ Ed. Jaypee Brothers Medical Publishers (P) Ltd. New Delhi; 2012: 1818, 1822, 1823.

5. Faris, A. A. (2010) Therapeutic Evaluation of a Unan Formulation in Waja'al-Mafãsil with Special Reference to estimation of retinol and tocopherol in patients, Department of Moalijat, Faculty of Medicine, Jamia Hamdard. New Delhi. p. 104106.

6. Masuya, Y. B. (1994) Al Mushajjar ul Kabir (Arabic), Khuda Bakhsh Oriental Public Library, Patna. p. 316-319.

7. Majusi, A. A. (1889) Kamil-us-Sana (Urdu translation), Matba Munshi Nawal Kishore, Lucknow. (2): 503-513, 521-522, 531534.

8. Qarah, S. B. (1928) Kitabul Dhakheera Fi Ilmut Tibb (Arabic), Al Matba ul Ameeriya, Cairo. p. 122-126.

9. Razi, Z. Kitab-al-Hawi Fit Tibb (Urdu translation), CCRUM, New Delhi. 2004; (11):75-188.

10. Rushd, I. (1987) Kitab al Kulliyat (Urdu translation), CCRUM, New Delhi. p. 384-385, 420-421.

11. Siddiqui, M. K. (2009) Unani Treatment of Waja-al-Mafasil, CCRUM, M/o. AYUSH New Delhi. p. 235-237

12. Tabri, A. R. (1417) Firdaus al Hikmat (Urdu translation), Sheikh Mohammad Bashir \& Sons, Lahore. p. 291-293,308.

13. Jurjani A.H (2010), Zakheera Khawarzam Shahi (Urdu Translation), Idara Kitabush Shifa, New Delhi, Volume VI, pp. 635-647.

14. Sina I (2004), Al Qanoon fit tibb (Urdu Translation), Idara Kitabush Shifa, New Delhi, Volume III, pp. 1119-1132.

15. Antaki D. TadhkiraAululAlbab (Arabic). Cairo: MaktabawaMatba Mohammad Ali SabeehwaAwlad; 1282 AH. p. 95-99

16. Kabiruddin, M. (2007) Moalijat Sharhe Asbab, Aijaz Publication House, New Delhi, Vol.3, pp. 164-165 


\section{Ahmad et al}

17. Kabeeruddin, M. (2003) Alakseer, Aijaz Publishing House, Delhi, Vol.5, pp.1431-47

18. Baig MG, Quamri MA, Ali J, Imtiyaz S, Sheeraz M, Zaheer N. Concept and Management of Waja-ul-Mafasil (Arthritis) in Greco Arabic Medicine- An Overview. Int J Cur Res Rev, 2014; 6 (20):41-47.

19. Kabiruddin (2005): Bayaz Kabir, Vol.II, Central Council for Research in Unani Medicine, New Delhi. pp50, 94.

20. Anonymous (1967): Qarabadeen Sarkari, Part II, Department of ISM, Govt. of AP., Hyderabad. pp. 45-46.

21. Anonymous (2006), National Formulary of Unani Medicine, Part I, Central Council for Research in Unani Medicine, Ministry of Health and family welfare, (Dept. of AYUSH) Govt. of India. 1st reprint,. pp. 200.

22. Mohammad I A, Tasleem A, Mohammad W A, Aisha P, Hashmat I, Nighat A, Naheed P.A. Clinical Study of Safety and Efficacy of Unani Pharmocopoeial Formulations of Habb-e-Suranjan and Raughan-e-Suranjan as Anti-arthritic Effect in Waja-al-Mafasil (Joints Pain), Hippocratic Journal of Unani Medicine, 2018; 13 (1): 9-16.

23. Anonymous (2008), The burden of pain among adults in the United States, Ptzer facts Findings from the National Health and Nutrition Examination Survey, the National Health Care Surveys, and the National Health Interview Survey, USA
Journal of Drug Delivery \& Therapeutics. 2021; 11(2-s):44-49

24. Srikanth VK, Fryer JL, Zhai G, Winzenberg TM, Hosmer D, Jones G; A meta-analysis of sex differences prevalence, incidence and severity of osteoarthritis; Osteoarthritis and Cartilage, 2005; 13(9):769-781. https://doi.org/10.1016/j.joca.04.014

25. Akhtar H, Husain SZ. Evaluation of Habb-e-Suranjan in Management of Primary Gout (Niqras). Journal of Ayurvedic and Herbal Medicine, 2019; 5(3):90-95.

26. Suhail S, jamil S, Jilani S, Ansari S, Yousuf A. Phytochemical and Pharmacological review of Suranjan shireen (Colchicum autumnale). Indo American Journal of Pharmaceutical Research, 2017; 7 (4):8492-96.

27. Suhail S, jamil S, Jilani S, Jahangir U, Qamar MW. Habb-eSuranjaan: A classical analgesic Unani formulation. Int J Adv Pharm Med Bio allied Sci. 2017; Vol. 2017; Issue 2017, Article ID 127: 1-6

28. Ghazanfar K, Dar SA, Nazir T, Akbar S. Sub chronic oral toxicity study of Habb-e-Suranjan in albino Wistar rats. Journal of Complementary and Integrative Medicine, 2018; DOI:10.1515/jcim-2017-0144.

29. Khan AA, Bashir F, Akhtar J, Anjum N, Shah Alam. Concept and Management of Waja'al-Mafasil (Arthritis) in Unani System of Medicine. Journal of Drug Delivery \& Therapeutics, 2019; 9(2s):634-639. 